\title{
$(\mathrm{Y}, \mathrm{Ce})-\mathrm{TZP} / \mathrm{Al}_{2} \mathrm{O}_{3}$ 複合体の HIP 処理と機械的強度及び水熱条件下の安定性
}

\author{
平野正典・松山辰夫・稲田 博・鈴木一孝* ·吉田晴男* ・町田充秀* \\ (株)ノリタケカンパニーリミテド，451名古屋市西区則武新町3-1-36 \\ *名古屋工業技術試験所，462名古屋市北区平手町1-1
}

\section{Stability under Hydrothermal Conditions and Fracture Strength of Yttria- and Ceria-Doped Tetragonal Zirconia/Alumina Composites Fabricated by HIPping}

\author{
Masanori HIRANO, Tatsuo MATSUYAMA, Hiroshi INADA, Kazutaka SUZUKI*, \\ Haruo YOSHIDA* and Michihide MACHIDA*
}

Noritake Co., Limited, 3-1-36, Noritake, Nishi-ku, Nagoya-shi 451

*Goverment Industrial Research Institute, Nagoya, 1-1, Hirate-cho, Kita-ku, Nagoya-shi 462

[Received July 2, 1990; Accepted October 26, 1990]

Yttria- and ceria-doped tetragonal zirconia ((Y, Ce)$\mathrm{TZP}) / \mathrm{Al}_{2} \mathrm{O}_{3}$ composites were fabricated by HIPping at $1400^{\circ}$ to $1600^{\circ} \mathrm{C}$ and $147 \mathrm{MPa}$ for $0.5 \mathrm{~h}$ in $\mathrm{Ar}$, and their bending strength, microstructure and stability under hydrothermal conditions at $180^{\circ} \mathrm{C}$ and $1 \mathrm{MPa}$ were studied. The bending strength of $(4 \mathrm{Y}, 4 \mathrm{Ce})-\mathrm{TZP} / 25 \mathrm{wt} \%$ $\mathrm{Al}_{2} \mathrm{O}_{3}$ composites HIPped at $1400^{\circ} \mathrm{C}$ was $1600 \mathrm{MPa}$. The thermal stability of $(\mathrm{Y}, \mathrm{Ce})-\mathrm{TZP} / \mathrm{Al}_{2} \mathrm{O}_{3}$ composites increased with decreasing HIP temperature, since it depends on the HIP temperature. (4Y, 4Ce)-TZP/25 wt $\%$ $\mathrm{Al}_{2} \mathrm{O}_{3}$ composites $\mathrm{HIPped}$ at $1400^{\circ} \mathrm{C}$ showed improved stability under hydrothermal conditions at $180^{\circ} \mathrm{C}$ and 1 $\mathrm{MPa}$. The composites treated at $1600^{\circ} \mathrm{C}$ showed marked grain growth as compared with $3 \mathrm{Y}-\mathrm{TZP} / \mathrm{Al}_{2} \mathrm{O}_{3}$ composites, and their bending strength was greatly reduced to less than that of normal sintered bodies. HIPping below $1500^{\circ} \mathrm{C}$ in $\mathrm{Ar}$ was useful to densify the composites and to improve the fracture strength.

Key-words : Hot isostatic pressing, Bending strength, Microstructure, Hydrothermal aging, Phase transformation, $(\mathrm{Y}, \mathrm{Ce})-\mathrm{TZP} / \mathrm{Al}_{2} \mathrm{O}_{3}$ composites

\section{1. 緒 言}

正方晶を室温で準安定のまま保持したジルコニア焼結体 は，相転移強化により著しい高強度，高勒性を示す．中で も $\mathrm{Y}_{2} \mathrm{O}_{3}$ を固溶した正方晶ジルコニア多結晶体（Y$\mathrm{TZP}^{1), 2)}$ ) は1000 MPa を越える強度3)を発現し，また低 温焼結が可能で構造材の一つとして広く応用が進められて いる。一方ホットプレスやHIP のような加圧焼結は残留 空孔の除去と低温焼結による結晶粒子成長の抑制に有効で ある、そこで高強度化を目的にジルコニアセラミックスの HIP 処理が行われ，3Y-TZP で1800〜 $1900 \mathrm{MPa}$ の曲げ強 度が報告されている(4),5)，Y-TZP と $\mathrm{Al}_{2} \mathrm{O}_{3}$ の複合体では HIP 処理により $2000 \mathrm{MPa}$ を越える強度が得られてい る6),7). しかしながらこれら $\mathrm{Y}_{2} \mathrm{O}_{3}$ を安定化剤とする正方 晶ジルコニアは，空気中 $200^{\circ} \sim 400^{\circ} \mathrm{C}$ の低温度で長時間保 持すると正方晶から単斜晶への相転移が生じ強度が劣化す
$3^{8), 9)}$ 。この相転移は水蒸気あるいは水の存在下では著し く促進される年 12)．この現象を改善するために種々の検 討が行われている13). $\mathrm{CeO}_{2}-\mathrm{ZrO}_{2}$ 系は状態図より $\mathrm{Y}_{2} \mathrm{O}_{3}-$ $\mathrm{ZrO}_{2}$ 系に比較し幅広い高温正方晶領域を有していること から Ce-TZPについての検討が行われている14). またY$\mathrm{TZP} に \mathrm{CeO}_{2}$ を添加した（Y, Ce)-TZP についての検討も 行われ，熱的に安定な TZP が報告されている15) 17).こ れらの TZP は十分な熱安定性を有しているが，Y-TZP に 比較すると機械的強度が劣っている.これに対し（Y, Ce)-TZP とアルミナからなる複合体は, Y-TZP に劣らぬ 曲げ強度と十分な熱安定性及び水熱条件下の安定性を示す ことが確認されている18).

本研究では焼結体の高強度化と熱的安定性の向上を目的 に, 安定化刘として $\mathrm{Y}_{2} \mathrm{O}_{3}$ と $\mathrm{CeO}_{2}$ を含むジルコニアとア ルミナからなる $(\mathrm{Y}, \mathrm{Ce})-\mathrm{TZP} / \mathrm{Al}_{2} \mathrm{O}_{3}$ 複合体の $\mathrm{HIP}$ 処理 を行った。特に予備焼結条件, HIP 処理温度と焼結体の 強度，水熱条件下に打ける正方晶の安定性について検討し た。

\section{2. 実験方法}

\section{1 試料の調製}

加水分解法によって得られた $\mathrm{Y}_{2} \mathrm{O}_{3}$ あるいは $\mathrm{Y}_{2} \mathrm{O}_{3}$ と $\mathrm{CeO}_{2}$ を安定化剂として含む表 1 に示す組成のジルコニア 粉末と $\alpha$-アルミナ（大明化学，TM-D，純度 $99.99 \%$ ）を 表 1 に示す割合で加え湿式混合した。得られた粉末を $19.6 \mathrm{MPa}$ の圧力で予備成形後, $196 \mathrm{MPa}$ の圧力で静水圧 成形した。成形体は大気中 $1350^{\circ} \sim 1600^{\circ} \mathrm{C}$ 温度で 2 時間 焼結し予備焼結体とした。

Table 1. Composition of specimens.

\begin{tabular}{|c|c|c|c|c|}
\hline \multirow{3}{*}{ Material } & \multirow{3}{*}{ Specimen } & \multicolumn{3}{|c|}{ Composition } \\
\hline & & \multicolumn{2}{|c|}{ Co-precipitated zirconia powder } & \multirow{2}{*}{$\begin{array}{c}\mathrm{Al}_{2} 0_{3} \\
(\mathrm{wt} \%)\end{array}$} \\
\hline & & Composition (mol\%) & (wt\%) & \\
\hline Y-TZP & $\mathrm{Y}$ & $3 \mathrm{Y}_{2} \mathrm{O}_{3} 97 \mathrm{ZrO}_{2}$ & 100 & 0 \\
\hline $\mathrm{Y}-\mathrm{TZP} / \mathrm{Al}_{2} \mathrm{O}_{3}$ & Y 25A & $3 \mathrm{Y}_{2} \mathrm{O}_{3} 97 \mathrm{ZrO} \mathrm{Z}_{2}$ & 75 & 25 \\
\hline$(\mathrm{Y}, \mathrm{Ce})-\mathrm{TZP} / \mathrm{Al}_{2} \mathrm{O}$ & $\mathrm{C} 25 \mathrm{~A}$ & $4 \mathrm{YO}_{1.5} 4 \mathrm{CeO}_{2} 92 \mathrm{ZrO}$ & 75 & 25 \\
\hline
\end{tabular}




\subsection{HIP 処理}

予備焼結体はグラファイト製のるつぼに入れ，グラファ イトヒーターを使用した研究用小型 HIP 装置を用い HIP 処理した。圧力媒体としては高純度 $\mathrm{Ar}$ ガスを使用し, $1400^{\circ}, 1500^{\circ}, 1600^{\circ} \mathrm{C} て ゙ 30$ 分間の HIP 処理を行った。昇

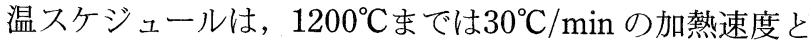
し, $1200^{\circ} \mathrm{C}$ か $1400^{\circ}, 1500^{\circ}, 1600^{\circ} \mathrm{C}$ の保持温度までは $10^{\circ} \mathrm{C} / \mathrm{min}$ とした。本実験の HIP 処理スケジュールを図 1 に示す.

\section{3 測 定}

密度測定はアルキメデス法によった．機械的強度は\# 140のダイヤモンド砥石で研削仕上げした $3 \times 4 \times 40 \mathrm{~mm}$ の試験片を用い，スパン幅 $30 \mathrm{~mm}$ ，クロスヘッド速度 0.5 $\mathrm{mm} / \mathrm{min}$ で 3 点曲げ強度を JISR1601に準じて測定した。 燒結体の破断面の微細組織は走査型電子顕微鏡 (SEM ; 日 立 S450）により観察した。水熱条件下の安定性は，\# 140 のダイヤモンド砥石で研削仕上した試料を用い， $180^{\circ} \mathrm{C}, 1 \mathrm{MPa}$ のオートクレーブ中で 1 回の保持時間を 5 時間とする図 2 に示すスケジュールの処理を繰り返し行い,

$\mathrm{X}$ 線回折により Garvie ら19)の方法を用いて表面相の同 定及び単斜晶相を定量し評価した。な打オートクレーブ処

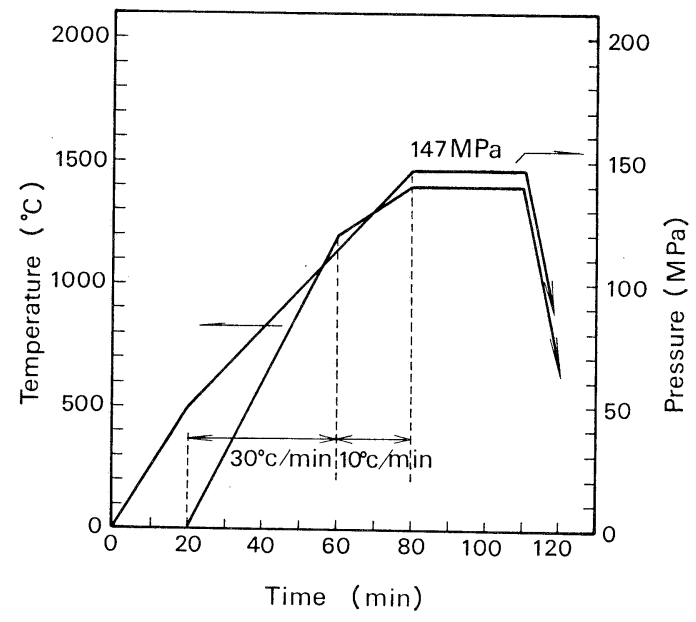

Fig. 1. HIP treating schedule.

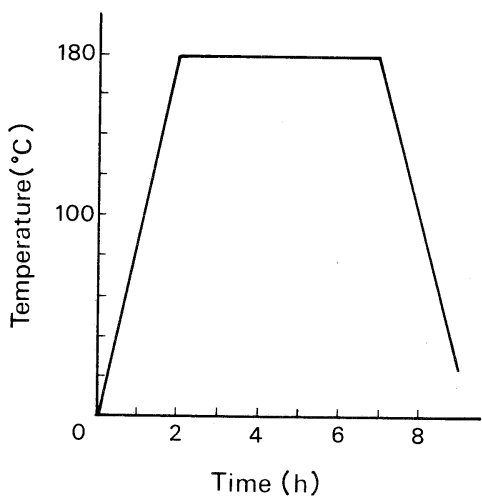

Fig. 2. Autoclave cycle.
理時間は, $180^{\circ} \mathrm{C}, 1 \mathrm{MPa}$ 条件での保持時間の合計とした。

\section{3. 結果及び考察}

\section{1 密度変化}

図 3 に HIP 処理前後の焼結体の密度変化を示す。なお 焼結体の相対密度は，TZP とアルミナの混合組成より， 3Y-TZP の真密度を $6.10 \mathrm{~g} / \mathrm{cm}^{3},(4 \mathrm{Y}, 4 \mathrm{Ce})-\mathrm{TZP}$ の真密度 を $6.12 \mathrm{~g} / \mathrm{cm}^{3}$, アルミナの真密度を $3.98 \mathrm{~g} / \mathrm{cm}^{3}$ として計 算した. 相対密度が95\%未満の予備焼結体では焼結体に 開気孔が残存しているため, HIP 処理によって完全には 緻密にならなかった。 予備焼結体の密度が $95 \%$ 以上の場 合には, HIP 処理によりほぼ理論密度付近まで緻密化し た.

図 4 に25 wt\%のアルミナを含む $\mathrm{Y}-\mathrm{TZP} / \mathrm{Al}_{2} \mathrm{O}_{3}$ と（Y, $\mathrm{Ce})-\mathrm{TZP} / \mathrm{Al}_{2} \mathrm{O}_{3}$ について $\mathrm{HIP}$ 処理温度と密度の関係を示 す. HIP 処理前の予備焼結体は, $\mathrm{Y}-\mathrm{TZP} / \mathrm{Al}_{2} \mathrm{O}_{3}$ が $96.2 \%,(\mathrm{Y}, \mathrm{Ce})-\mathrm{TZP} / \mathrm{Al}_{2} \mathrm{O}_{3}$ が98.5\%の相対密度であり, いずれも $1400^{\circ} \mathrm{C}$ のIP 処理によってほぼ理論密度まで緻

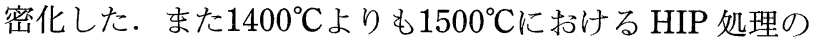

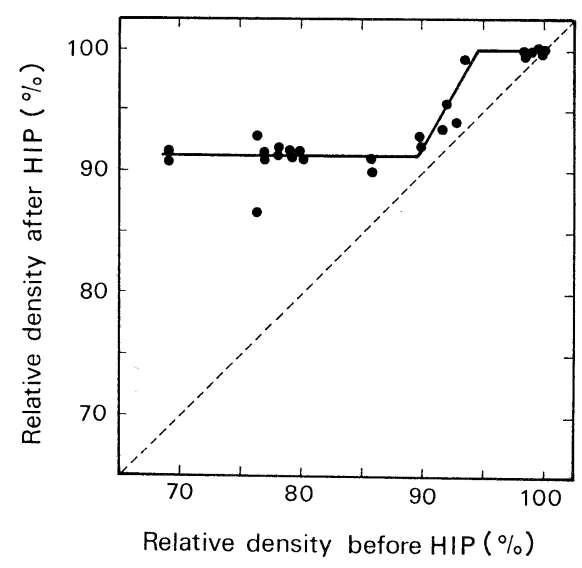

Fig. 3. Density bofere and after HIPping.

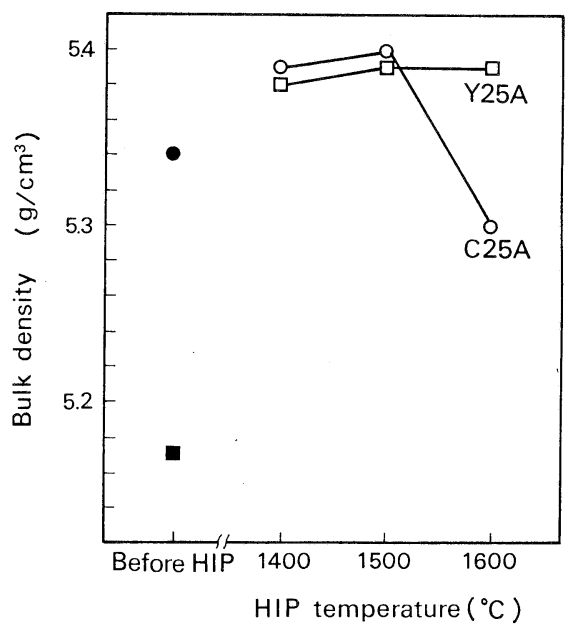

Fig. 4. Bulk density of $\mathrm{TZP} / \mathrm{Al}_{2} \mathrm{O}_{3}$ composites presintered at $1400^{\circ} \mathrm{C}$ for $2 \mathrm{~h}$, then HIPped at various temperatures for $0.5 \mathrm{~h}$. 
方がやや密度は高くなった、 $\mathrm{Y}-\mathrm{TZP} / \mathrm{Al}_{2} \mathrm{O}_{3}$ の $\mathrm{HIP}$ 処理体 の密度は, $1400^{\circ} \sim 1600^{\circ} \mathrm{C}$ 処理温度範囲で温度に大きく 依存しなかった。これに対して ( $\mathrm{Y}, \mathrm{Ce})-\mathrm{TZP} / \mathrm{Al}_{2} \mathrm{O}_{3}$ で は，処理温度を $1600^{\circ} \mathrm{C}$ とた場合に処理前よりも密度が 低下した. $\mathrm{X}$ 線回折の結果, $1600^{\circ} \mathrm{C} て ゙$ 処理した $(\mathrm{Y}, \mathrm{Ce})$ $\mathrm{TZP} / \mathrm{Al}_{2} \mathrm{O}_{3}$ では単斜晶ジルコニアの生成が諗められた. この結果加ら, $1600^{\circ} \mathrm{C} て ゙ \mathrm{HIP}$ 処理した ( $\left.\mathrm{Y}, \mathrm{Ce}\right)-\mathrm{TZP} / \mathrm{Al}_{2}$ $\mathrm{O}_{3}$ の密度低下は単斜晶ジルコニアの生成が原因と考えら れる。

\section{2 機械的強度及び微細組織}

$25 \mathrm{wt} \%$ のルミナを含有する $(\mathrm{Y}, \mathrm{Ce})-\mathrm{TZP} / \mathrm{Al}_{2} \mathrm{O}_{3}$ の HIP 処理温度と焼結体の曲げ強度の関係を図 5 に示す。 $1500^{\circ} \mathrm{C}$ の大気中で焼結を行った複合体の平均曲げ強度は $1050 \mathrm{MPa}$ であった。これに対し $1400^{\circ} \mathrm{C}$ の HIP 処理体は $1600 \mathrm{MPa}$ の平均強度を示し, HIP 処理による高強度化 が達成された。しかしながら $1500^{\circ} \mathrm{C}$ の HIP 処理体では $1500 \mathrm{MPa}, 1600^{\circ} \mathrm{C}$ の HIP 処理体では試料表面に微小なク ラックが観察され，600 MPa と一段と低い強度になった。 このように ( $\mathrm{Y}, \mathrm{Ce})-\mathrm{TZP} / \mathrm{Al}_{2} \mathrm{O}_{3}$ では処理温度が高くなる と急激に強度が低下した. Y-TZP $/ \mathrm{Al}_{2} \mathrm{O}_{3}$ では処理温度に 対するこのような急激な強度低下現象は見られなかった。

図 6 に $\mathrm{Y}-\mathrm{TZP} / \mathrm{Al}_{2} \mathrm{O}_{3}$ 亡 $(\mathrm{Y}, \mathrm{Ce})-\mathrm{TZP} / \mathrm{Al}_{2} \mathrm{O}_{3} の 1400^{\circ}$, $1600^{\circ} \mathrm{C}$ 各 HIP 処理体の破断面の SEM 写真を示す。いず

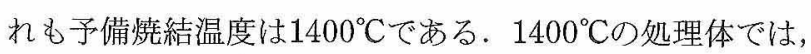
$(\mathrm{Y}, \mathrm{Ce})-\mathrm{TZP} / \mathrm{Al}_{2} \mathrm{O}_{3}$ の方が $\mathrm{Y}-\mathrm{TZP} / \mathrm{Al}_{2} \mathrm{O}_{3}$ よりもわずかに ジルコニア粒子の粒径が大きいが，いずれも約 $0.5 \mu \mathrm{m}$ 以 下の微細な粒子からなっていた。 $1600^{\circ} \mathrm{C} の$ 処理体では著 しい粒成長が見られた，特に $(\mathrm{Y}, \mathrm{Ce})-\mathrm{TZP} / \mathrm{Al}_{2} \mathrm{O}_{3}$ に抢け る粒成長は $\mathrm{Y}-\mathrm{TZP} / \mathrm{Al}_{2} \mathrm{O}_{3}$ に比べて顕著であった。

図 7 HIP 処理した $(\mathrm{Y}, \mathrm{Ce})-\mathrm{TZP} / \mathrm{Al}_{2} \mathrm{O}_{3}$ の曲げ強度 と予備焼結温度の関係を示す. HIP 処理温度が $1400^{\circ} \mathrm{C} の$ 場合, 予備焼結温度が $1400^{\circ} \mathrm{C}$ 試料では強度のばらつき が大きく, $1450^{\circ} \sim 1500^{\circ} \mathrm{C}$ 試料が最も高い強度を示した.

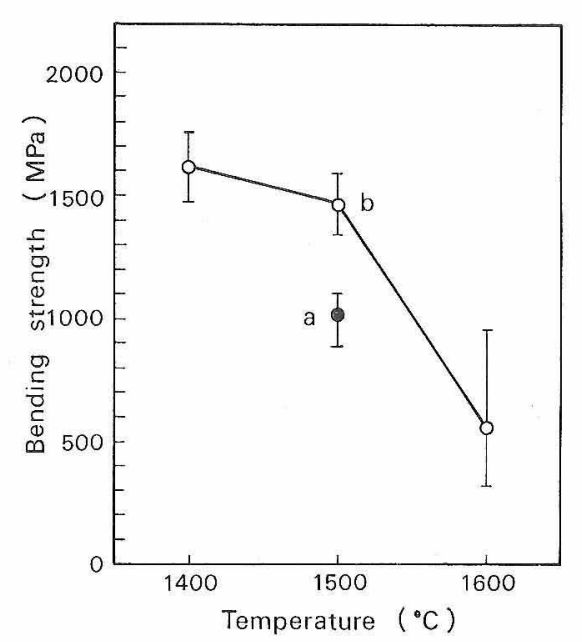

Fig. 5. Relation between bending strength and sintering temperature of $(4 \mathrm{Y}, 4 \mathrm{Ce})-\mathrm{TZP} / 25 \mathrm{wt} \% \mathrm{Al}_{2} \mathrm{O}_{3}$ composites. (a) normally sintered in air and (b) presintered at $1450^{\circ} \mathrm{C}$ for $2 \mathrm{~h}$, then HIPped for $0.5 \mathrm{~h}$.
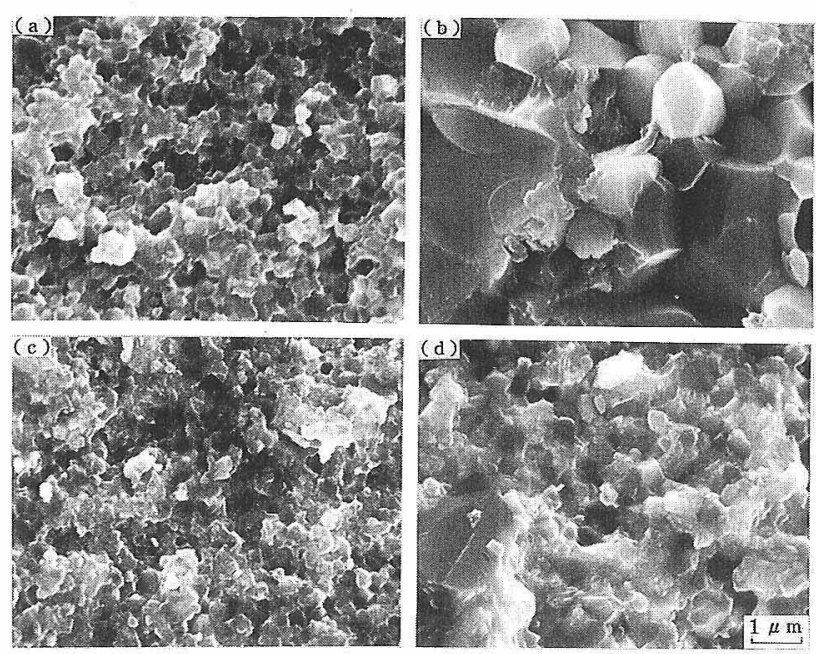

Fig. 6. SEM photographs of the fracture surface of $\mathrm{TZP} / \mathrm{Al}_{2} \mathrm{O}_{3}$ composites.

(a) $(4 \mathrm{Y}, 4 \mathrm{Ce})-\mathrm{TZP} / 25 \mathrm{wt} \% \mathrm{Al}_{2} \mathrm{O}_{3}$ composites HIPped at $1400^{\circ} \mathrm{C}$, (b) $(4 \mathrm{Y}, 4 \mathrm{Ce})-\mathrm{TZP} / 25 \mathrm{wt} \% \mathrm{Al}_{2} \mathrm{O}_{3}$ composites HIPped at $1600^{\circ} \mathrm{C}$,

(c) $3 \mathrm{Y}-\mathrm{TZP} / 25 \mathrm{wt} \% \mathrm{Al}_{2} \mathrm{O}_{3}$ composites HIPped at $1400^{\circ} \mathrm{C}$,

(d) $3 \mathrm{Y}-\mathrm{TZP} / 25 \mathrm{wt} \% \mathrm{Al}_{2} \mathrm{O}_{3}$ composites HIPped at $1600^{\circ} \mathrm{C}$.

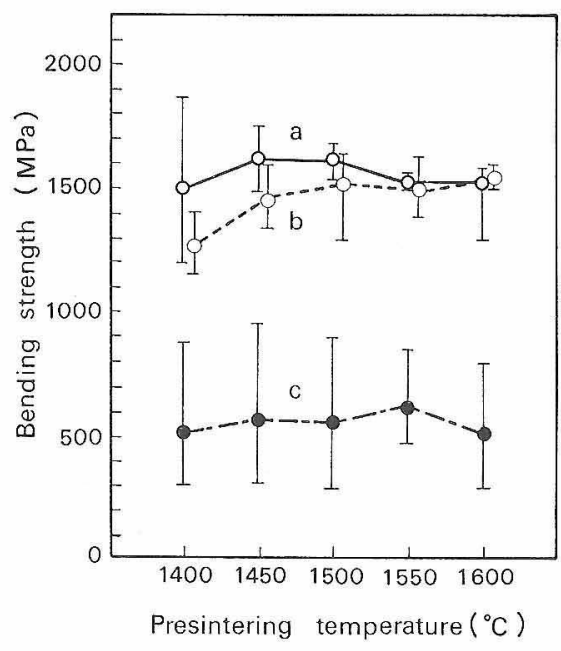

Fig. 7. Relation between bending strength and presintering temperature of $(4 \mathrm{Y}, 4 \mathrm{Ce})-\mathrm{TZP} / 25 \mathrm{wt} \% \mathrm{Al}_{2} \mathrm{O}_{3}$ composites fabricated by HIPping at (a) $1400^{\circ} \mathrm{C}$, (b) $1500^{\circ} \mathrm{C}$ and (c) $1600^{\circ} \mathrm{C}$.

HIP 処理温度が $1400^{\circ}, 1500^{\circ} \mathrm{C}$ では，予備焼結温度が HIP 処理温度より高い場合であっても約1500 MPa の平均曲げ 強度を示し, 高強度な複合体が得られた。このように HIP 処理温度が $1500^{\circ} \mathrm{C}$ 以下においては，焼結体の強度は 約 $1500 \mathrm{MPa}$ であり， $1400^{\circ} \sim 1600^{\circ} \mathrm{C}$ 範囲で予備焼結温 度に大きく依存しないことが分かる. HIP 処理温度が $1600^{\circ} \mathrm{C}$ の場合は，いずれも予備焼結温度の影響をあまり 受けず約 $600 \mathrm{MPa}$ と低強度であった。

また，実験で得られた HIP 処理体は，いずれも大気中 での常圧焼結体と異なる色を呈していた。すなわち $\mathrm{Y}$ $\mathrm{TZP} / \mathrm{Al}_{2} \mathrm{O}_{3}$ の場合は，常圧焼結体が白色であるのに対し $\mathrm{HIP}$ 処理体は灰色であった。 ( $\mathrm{Y}, \mathrm{Ce})-\mathrm{TZP} / \mathrm{Al}_{2} \mathrm{O}_{3}$ の場合 は，常圧焼結体が黄色味を帯びた白色であるのに対し 
HIP 処理体は茶褐色であった。正木20)はグラファイト ヒーターを使用したY-TZP の HIP 処理に関し, HIP 処 理体が微量なカーボンを含有するため, $1000^{\circ} \mathrm{C}$ 付近の高 温にて長時間エージングを行うと含有カーボンが酸化し， 強度が劣化する現象を報告している．本実験で得られた HIP 処理体も同様に，グラファイト製のるつぼびヒー ターを使用した $\mathrm{Ar}$ 雾囲気中での処理であるため, 着色原 因の一つとして $(\mathrm{CO}+\mathrm{Ar})$ 雾囲気下の $\mathrm{HIP}$ 処理による 微量なカーボンの侵入が考えられる。また $\mathrm{CeO}_{2}$ を安定化 剂として用いた TZP は，非酸化性雾囲気下の高温熱処理 によってTZP に固溶している $\mathrm{CeO}_{2}$ が徐々に $\mathrm{Ce}_{2} \mathrm{O}_{3}$ へ還 元される21)ことから, $(\mathrm{Y}, \mathrm{Ce})-\mathrm{TZP} / \mathrm{Al}_{2} \mathrm{O}_{3}$ の着色は, 微 量カーボンの侵入のほか， $(\mathrm{CO}+\mathrm{Ar})$ 雾囲気下で $\mathrm{CeO}_{2}$ が $\mathrm{Ce}_{2} \mathrm{O}_{3}$ へ還元されたことが原因と考えられる。なお（ $\mathrm{Y}$, $\mathrm{Ce})-\mathrm{TZP} / \mathrm{Al}_{2} \mathrm{O}_{3}$ の HIP 処理による着色については, 高温 で HIP 処理した焼結体の方が低温で HIP 処理した焼結体 よりも濃い色を呈していた．着色度合いから推察すると， $(\mathrm{Y}, \mathrm{Ce})-\mathrm{TZP} / \mathrm{Al}_{2} \mathrm{O}_{3}$ に含有される $\mathrm{CeO}_{2}$ の還元は, $1400^{\circ} \mathrm{C}$ よりも $1600^{\circ} \mathrm{C}$ 付近の高温下の処理において急速に 進展するものと考えられる.

以上の実験結果を総合すると, 図 5 及び図 7 に見られ る $\mathrm{HIP}$ 処理温度の上昇に伴う $(\mathrm{Y}, \mathrm{Ce})-\mathrm{TZP} / \mathrm{Al}_{2} \mathrm{O}_{3}$ の密 度及び強度低下は, 次のような原因によると考えられる。 グラファイトヒーターを使用した $(\mathrm{CO}+\mathrm{Ar})$ 雾囲気下に おける $1600^{\circ} \mathrm{C}$ という高温 HIP 処理により，(1) TZP の安 定化剂である $\mathrm{CeO}_{2}$ が一部 $\mathrm{Ce}_{2} \mathrm{O}_{3}$ へ還元された。 (2) $\mathrm{CeO}_{2}$ の還元及び粒成長により, 正方晶から単斜晶へのジルコニ アの相転移が進展し，焼結体中に微小なクラックが発生し た。このような原因により密度及び強度低下が生じたと考 えられる。

\section{3 水熱条件下の安定性}

図 8 に $180^{\circ} \mathrm{C}, 1 \mathrm{MPa}$ の水熱条件下でオートクレーブ処 理を行い, 各 HIP 処理体の水熱条件下の安定性について 調べた結果を示す. $1500^{\circ} \mathrm{C}$ で常圧焼結した Y-YZP に比較 し， $25 \mathrm{wt} \%$ のアルミナを含有する $1400^{\circ} \mathrm{C} の \mathrm{HIP}$ 処理体 は，水熱条件下に扔いてかなり安定で単斜晶の増大も少な い. Y-TZP $/ \mathrm{Al}_{2} \mathrm{O}_{3}$ と ( $\left.\mathrm{Y}, \mathrm{Ce}\right)-\mathrm{TZP} / \mathrm{Al}_{2} \mathrm{O}_{3}$ を比較すると, $(\mathrm{Y}, \mathrm{Ce})-\mathrm{TZP} / \mathrm{Al}_{2} \mathrm{O}_{3}$ がより安定で20時間処理後の正方晶 から単斜晶への相転移量も $10 \%$ 以下であり，5 時間処理後 からの変化が少ない．Y-TZPは，5１0時間のオートク レーブ処理で焼結体表面の正方晶はほぼすべて単斜晶へ相 転移し，10時間以上のオートクレーブ処理に抢いては焼 結体表面から内部へ徐々に劣化が進展しているものと考元 られる。

図 9 に $\mathrm{Y}-\mathrm{TZP} / \mathrm{Al}_{2} \mathrm{O}_{3}$ と $(\mathrm{Y}, \mathrm{Ce})-\mathrm{TZP} / \mathrm{Al}_{2} \mathrm{O}_{3}$ を比較し, HIP 処理温度と水熱条件下の安定性について調べた結果 を示す、いずれも HIP 処理温度が低い $1400^{\circ} \mathrm{C}$ 処理体の方 が劣化は少なく，また $\mathrm{Y}-\mathrm{TZP} / \mathrm{Al}_{2} \mathrm{O}_{3}$ に比べ $(\mathrm{Y}, \mathrm{Ce})$ $\mathrm{TZP} / \mathrm{Al}_{2} \mathrm{O}_{3}$ は相対的に相転移量が少ないことが分かる.

これらの結果から, $1400^{\circ} \mathrm{C}$ 付近の比較的低温で HIP 処理 した $(\mathrm{Y}, \mathrm{Ce})-\mathrm{TZP} / \mathrm{Al}_{2} \mathrm{O}_{3}$ は高い熱安定性を有することが

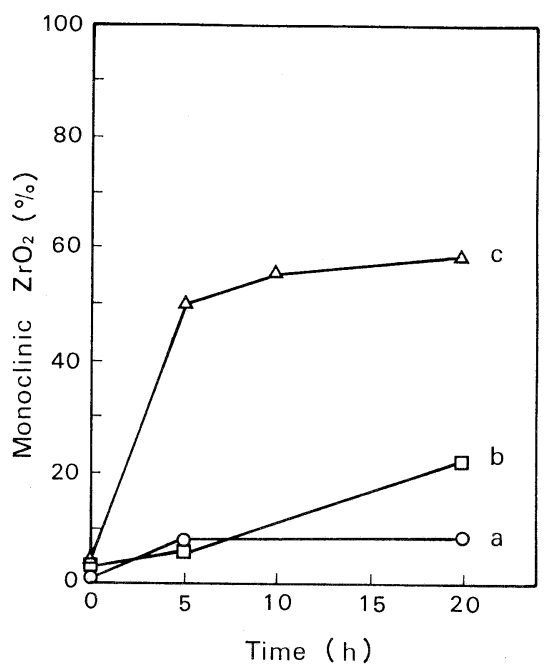

Fig. 8. Results of hydrothermal aging at $180^{\circ} \mathrm{C}$ and $1 \mathrm{MP}$ for (a) (4Y, 4Ce)-TZP $/ 25$ wt $\% \mathrm{Al}_{2} \mathrm{O}_{3}$ and (b) $3 \mathrm{Y}-\mathrm{TZP} / 25 \mathrm{wt} \% \mathrm{Al}_{2} \mathrm{O}_{3}$ composites fabricated by HIPping at $1400^{\circ} \mathrm{C}$ and (c) $3 \mathrm{Y}$-TZP fabricated by normal sintering at $1500^{\circ} \mathrm{C}$.

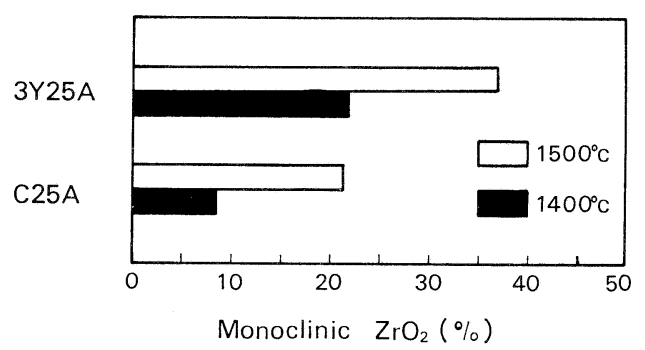

Fig. 9. Tetragonal-to-monoclinic phase transformation resulting from hydrothermal aging at $180^{\circ} \mathrm{C}$ and $1 \mathrm{MPa}$ for $20 \mathrm{~h}$ for $3 \mathrm{Y}$ $\mathrm{TZP} / 25 \mathrm{wt} \% \mathrm{Al}_{2} \mathrm{O}_{3}$ and $(4 \mathrm{Y}, 4 \mathrm{Ce})-\mathrm{TZP} / 25 \mathrm{wt} \% \mathrm{Al}_{2} \mathrm{O}_{3}$ composites fabricated by HIPping at $1400^{\circ} \mathrm{C}$ and $1500^{\circ} \mathrm{C}$.

明らかとなった。

\section{4. 総 括}

(4Y, $4 \mathrm{Ce})-\mathrm{TZP} / 25 \mathrm{wt} \% \mathrm{Al}_{2} \mathrm{O}_{3}$ 複合体を $1400^{\circ} \sim 1600^{\circ} \mathrm{C}$, $147 \mathrm{MPa}, 0.5 \mathrm{~h}$ の条件で HIP 処理し, 予備焼結条件, HIP 処理条件之得られた焼結体の機械的強度及び水熱条 件下の安定性について検討し，次の知見を得た。

(1) $\mathrm{HIP}$ 処理により高強度の $(\mathrm{Y}, \mathrm{Ce})-\mathrm{TZP} / \mathrm{Al}_{2} \mathrm{O}_{3}$ 複合 体が得られ，その曲げ強度は $1600 \mathrm{MPa}$ であった。

(2) $\mathrm{HIP}$ 処理温度が $1400^{\circ} \mathrm{C} の(\mathrm{Y}, \mathrm{Ce})-\mathrm{TZP} / \mathrm{Al}_{2} \mathrm{O}_{3}$ は, $1400^{\circ} \mathrm{C}$ の予備焼結条件では強度のばらつきが大きく, $1450^{\circ} \sim 1500^{\circ} \mathrm{C}$ に扔いて最も平均強度が高くなった。

（3） HIP 処理温度が低い焼結体では水熱条件下の安定 性が高く, $1400^{\circ} \mathrm{C}$ で処理した $(\mathrm{Y}, \mathrm{Ce})-\mathrm{TZP} / \mathrm{Al}_{2} \mathrm{O}_{3}$ は単斜 晶への相転移をほとんど生じなかった。

(4) $1600^{\circ} \mathrm{C}$ の高温で $\mathrm{HIP}$ 処理した $(\mathrm{Y}, \mathrm{Ce})-\mathrm{TZP} / \mathrm{Al}_{2} \mathrm{O}_{3}$ は, $\mathrm{Y}-\mathrm{TZP} / \mathrm{Al}_{2} \mathrm{O}_{3}$ に比較し粒成長が著しく, 曲げ強度は 約600 MPa と低い值となった。 


\section{文献}

1) T. K. Gupta, J. H. Bechtold, R. C. Kuznicki, L. H. Cadoff and B. R. Rossing, J. Mater. Sci., 12, 2421-26 (1977).

2) T. K. Gupta, F. F. Lange and J. H. Bechtold, J. Mater. Sci., 13, 1464-70 (1978).

3）津久間孝次, 宔田吉孝, 月舘隆明, 窯協, 92, 11-19 (1984).

4) K. Tsukuma and M. Shimada, Am. Ceram. Soc. Bull., 64, 310-13 (1985).

5）立野常男, 本間克彦, “ジルコニアセラミックス, 5”内田 老鶴圃（1985） pp. 27-30.

6) K. Tsukuma, K. Ueda and M. Shimada, J. Am. Ceram. Soc., 68, C-5 (1985).

7）四方良一，浦田佳孝，塩野剛司，西川友三，粉体および粉 末治金，37, 357-61 (1990).

8) K. Kobayashi, H. Kawajima and T. Masaki, Solid State Ion., 3-4, 489 (1981).

9) T. Sato, S. Ohtaki and M. Shimada, J. Mater. Sci., 20, 146670 (1985).

10) T. Sato and M. Shimada, J. Am. Ceram. Soc., 68, 356-59
(1985).

11) 吉村昌弘, 野間竜男, 川端勝一, 宗宮重行, セラミックス 論文誌，96, 265-70 (1988).

12）重松利彦, 中西典彦, “ジルコニアセラミックス, 9”, 内田 老鶴固 (1987) pp. 63-71.

13）佐藤次雄, 島田昌彦, 表面科学, 10, 11-17 (1989).

14) K. Tsukuma, Am. Ceram. Soc. Bull., 65,1386-89 (1986).

15）渡辺俊也, 浦部和順, 井川博行, 宇田川重和, 昭和59年割 業協会年会講演予稿集 (1984) pp. 463-64.

16）佐藤次雄, 大滝史郎, 遠藤 忠, 島田昌彦, “ジルコニアセ ラミックス，5”，内田老鶴國 (1985) pp. 75-85

17）平野正典，稲田 博，セラミックス論文誌，99, 23-29 (1991)

18）平野正典, 稲田 博, セラミックス論文誌, 99, 124-30 (1991).

19) R. C. Garvie and P. S. Nickolson, J. Am. Ceram. Soc., 55, 303 (1972).

20) T. Masaki, J. Am. Ceram. Soc., 69, 519-22 (1986).

21) K. H. Heussner and N. Claussen, J. Am. Ceram. Soc., 72, 1044-46 (1989). 